\title{
Usefulness of a Novel Staging System for Congenital Cholesteatoma of the Middle Ear
}

\author{
Byeong Joon Kim, Ju Ho Han, Jeong Hwan Yang, Sung Kwang Hong, \\ Hyo Jeong Lee, and Hyung-Jong Kim \\ Department of Otorhinolaryngology-Head and Neck Surgery, Hallym University College of Medicine, Anyang, Korea
}

\author{
새로운 선천성 중이진주종 병기분류의 유용성 \\ 김병준 · 한주호 · 양정환 · 홍성광 · 이효정 · 김형종 \\ 한림대학교 의과대학 이비인후-두경부외과학교실
}

\author{
Received January 27, 2019 \\ Revised May 13, 2019 \\ Accepted May 20, 2019 \\ Address for correspondence \\ Hyung-Jong Kim, MD, PhD \\ Department of Otorhinolaryngology- \\ Head and Neck Surgery, \\ Hallym University \\ College of Medicine, \\ 22 Gwanpyeong-ro 170beon-gil, \\ Dongan-gu, Anyang 14068, Korea \\ Tel $+82-31-380-3842$ \\ Fax +82-31-386-3860 \\ E-mail hjk1000@hallym.or.kr
}

Background and Objectives Although there are number of studies on the risk factors of recidivism in the congenital middle ear cholesteatoma, few have focused on the staging system. In this study, we aimed to investigate the postoperative recurrence rate in surgical cases of congenital middle ear cholesteatoma, and compare the results of using the Potsic staging system with those of a novel Kim staging system. Additionally, we also studied to see if the Kim staging system could suggest an appropriate surgical approach for each stage.

Subjects and Method Surgical cases of the disease from January, 1989 to August, 2017 performed at Kangdong Sacred Heart or Hallym University Sacred Heart Hospital were included and those data were retrospectively reviewed. All the cases were pre-operatively assigned to the stages using both Potsic and Kim staging system, retrospectively. The post-operative recurrence rate was analyzed for each subject according to the findings of one year after surgery using both staging systems. Additionally, surgical approach performed in these cases, such as mastoidectomy and/or ossiculoplasty were analyzed and compared among the stage groups of Kim staging system.

Results The Potsic staging system showed that recurrence was significantly lower in the stage I than in the other stages, and the Kim staging system showed that recurrence was significantly higher in the revision R stage than in the primary A, P, and M stages. The Kim staging system showed that mastoidectomy was performed more frequently in the M stage, and ossiculoplasty was performed less frequently in the A stage than in the other stages.

Conclusion Although Potsic and Kim staging systems were both useful for predicting prognosis, the Kim staging system can additionally provide a clue for an appropriate surgical approach for each stage.

Korean J Otorhinolaryngol-Head Neck Surg 2019;62(11):617-23

Key Words Cholesteatoma $\cdot$ Classification $\cdot$ Congenital $\cdot$ Recurrence.

\section{서 론}

선천성 중이진주종은 일반적으로 정상고막 내측에 출생 시 부터 존재하는 회백색 상피 낭종의 형태로 나타나며 상고실,

This is an Open Access article distributed under the terms of the Creative Commons Attribution Non-Commercial License (https://creativecommons.org/licenses/by-nc/4.0) which permits unrestricted non-commercial use, distribution, and reproduction in any medium, provided the original work is properly cited.
유양동, 측두골의 추체부까지 진행된 병변을 보이기도 한다. ${ }^{1-3)}$ 전체 진주종 중 2 5\%로 그리 드물지 않은 것으로 알려져 있 으며) 최근에는 이내시경을 이용한 진단 기술이 좋아지면서 발생빈도가 점차 증가하는 추세를 보이고 있다.5) 임상적으로 정상고막 안쪽으로 백색 종물이 비추어 보이면서 과거력상 귀 수술이나 외상, 또는 고막 천공이 없는 경우에 진단할 수 있다. ${ }^{6,7}$ 
진주종의 치료는 외과적 절제술이 원칙이며 병변의 위치 와 범위에 따라 실험적 고실개방술, 고실성형술, 또는 유양돌 기절제술을 등을 적절히 선택해야 한다. ${ }^{7)}$ 하지만, 적절한 수 술 방법의 선택에도 불구하고, 소아의 선천성 중이진주종은 성인의 경우보다 흔히 광범위한 측두골 침범, 이소골의 손상, 미로의 병변 등으로 인하여 수술이 어려운 경우가 많고 재발 률이 29.5 52\%에 달하는 것으로 알려져 있다. ${ }^{6,8-10)}$ 이처럼 높은 재발률로 인해 선천성 중이진주종의 재발 위험인자에 대하여 국내외 많은 연구가 진행되고 있고 현재까지 이소골 손상 여부, 진주종의 유형 등 몇 가지 예후인자들이 보고되 었다.11-13) 하지만 이들 중 예후인자로서 진주종의 병기에 주 목한 연구는 많지 않은 실정이다.

현재까지 알려진 선천성 중이진주종의 병기체계로는 Nelson 등 $^{14)}$ 의 병기와 Potsic 등 ${ }^{10)}$ 의 병기가 있는 가운데, 본 연 구에서는 기존에 널리 쓰이던 병기인 Potsic 등 $^{10)}$ 의 병기와 본 교실에서 2013년 새롭게 제안한 $\mathrm{Kim}^{5}$ 의 병기를 사용하여 두 병기에 따른 재발률의 차이를 분석하여 그 유용성을 알 아보고자 하였다. 또한, $\mathrm{Kim}^{5)}$ 의 병기에 따라 환자를 분류하 였을 때 병기에 따른 수술 접근법의 차이가 있는지 분석함으 로써 이 질환의 수술계획 수립에 도움이 되고자 하였다.

\section{대상 및 방법}

\section{연구 대상}

1989년 1월부터 2017년 8월까지 한림대학교 성심병원 및 강동성심병원을 내원하여 선천성 중이진주종 진단하에 수술 적 치료를 받은 환자들을 대상으로 하였으며, 수술기록을 포 함한 의무기록 자료와 2005년 대한이과학회에서 배포한 중 이수술 데이터베이스 프로그램에 저장/관리된 자료를 이용 하여 후향적 분석을 시행하였다. 연구기간 동안 만성중이염,
진주종 및 선천성 진주종으로 본원에서 수술을 받은 환자의 수는 각각 4580예, 1100예 및 142예로 선천성 중이진주종은 전체 만성중이염 환자의 $3.1 \%$ 에 해당하였으며, 전체 진주종 환자 중 $12.9 \%$ 에 해당하였다(Fig. 1). 총 142예의 선천성 중 이진주종 모두 전신마취하 수술로 시행되었고, 같은 기간에 단일 술자에 의해 시행된 수술례만 연구 대상에 포함하였다. 142예 중 첫 수술(primary operation)로서 시행받은 경우는 112예였으며 술 후 재발되어 재수술(revision operation)로서 시행받은 경우는 30 예였다. 재수술을 시행받은 30 예 중 둘째 수술을 받은 22예는 본원에서 첫 수술을 받고 재발한 17예 와 외부에서 첫 수술을 받은 후 재발한 5예가 포함되었고, 세 번째 수술을 받은 경우는 6예 그리고 네 번째와 다섯 번째 수술을 받은 경우는 각각 1예가 있었다. 첫 수술군은 남자가 80예, 여자가 32예, 평균 연령은 7.2세였고, 재수술군은 남자 가 24예, 여자가 6예. 평균 연령은 9.4세였고, 두 번째 수술을 받은 22예만 따로 보면 남자가 16예(3 17세, 평균 나이 9.2세) 여자가 6예(7 22세, 평균 나이 12.5세)였다.

\section{환자 분류}

모든 대상 환자는 임상적으로 술 전 고막 소견 및 영상의 학적으로 전산화측두골단층촬영(temporal bone computerized tomography, TBCT) 소견을 참고하여 Potsic 등 ${ }^{10)}$ 의 병기체계 및 최근 새롭게 제안된 $\mathrm{Kim}^{5)}$ 의 병기체계를 사용 하여 각각의 병기를 분류하였다. Potsic 등 ${ }^{10)}$ 의 병기 I기는 중 이 내 하나의 quadrant에 국한된 병변, II기는 둘 이상의 quadrant 병변이나 이소골 침범, 유양동 침범은 없음, III기 는 이소골 침범이 있고, 유양동 침범은 없음, IV기는 유양동 침범이 있음의 4단계로 그리고, $\mathrm{Kim}^{5)}$ 의 $\mathrm{A}$ 병기는 고실 전방 부위 병변, $\mathrm{P}$ 병기는 고실 후방 부위 병변이며 이소골 침범 유 무와는 무관하고, 유양동 침범은 없음, $\mathrm{M}$ 병기는 유양동 침

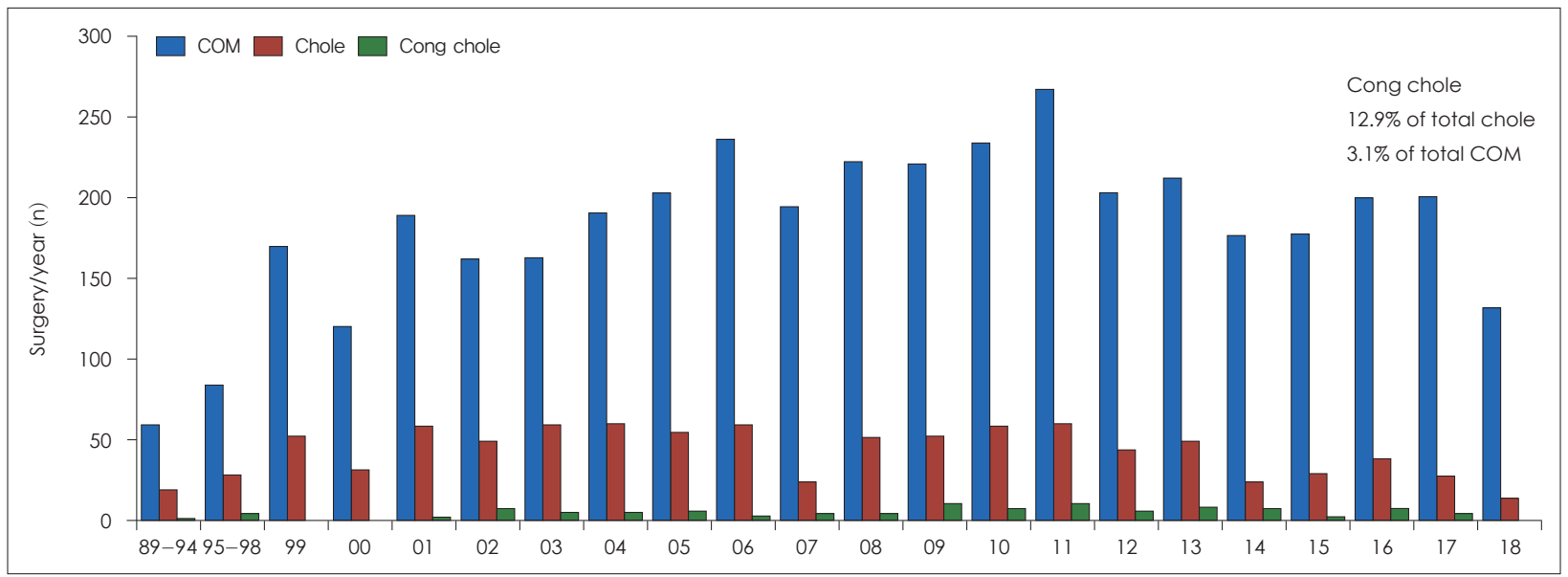

Fig. 1. Increasing trend of Cong chole surgery. COM: chronic otitis media, Cong chole: congenital chole steatoma. 
Table 1. Staging systems for congenital cholesteatoma of the middle ear based on disease extent and proposed surgical approach according to Potsic, and Kim

\begin{tabular}{|c|c|c|c|}
\hline Author & Stage & Description & Surgical approach \\
\hline \multirow[t]{3}{*}{ Potsic et al. ${ }^{10)}$} & $1-\|$ & $\begin{array}{l}\text { Involves one (I) or more (II) middle ear quadrants } \\
\text { without ossicular invasion or mastoid extension }\end{array}$ & Not provided \\
\hline & III & Ossicular erosion but no mastoid extension & Not provided \\
\hline & IV & Mastoid infiltration & Tympanomastoidectomy \\
\hline \multirow[t]{4}{*}{$\mathrm{Kim}^{5}$} & A & Anterior quadrant & Exploratory tympanotomy with/without atticotomy \\
\hline & $P$ & $\begin{array}{l}\text { Posterior quadrant with or without ossicular } \\
\text { involvement } \\
\text { No mastoid involvement }\end{array}$ & $\begin{array}{l}\text { Exploratory tympanotomy with atticotomy } \\
\text { Canal up mastoidectomy with exploratory } \\
\text { tympanotomy }\end{array}$ \\
\hline & M & Mastoid involvement & $\begin{array}{l}\text { Canal up mastoidectomy with/without exploratory } \\
\text { tympanotomy }\end{array}$ \\
\hline & $R$ & Recidivistic cases & $\begin{array}{l}\text { Managed as primary cases, and canal down } \\
\text { mastoidectomy, if necessary }\end{array}$ \\
\hline
\end{tabular}
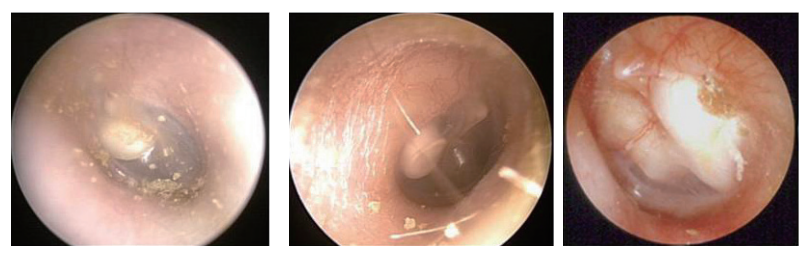

Anterior
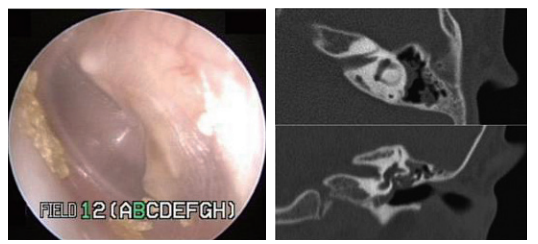

Mastoid extension

Posterior

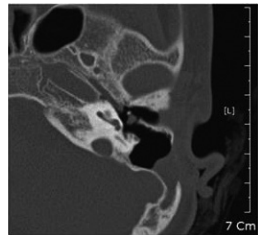

Recidivistic

Fig. 2. Classification of congenital cholesteatoma of the middle ear using Kim's staging system. Adapted from Kim. Korean J Otorhinolaryngol-Head Neck Surg 2013:56(8);486. ${ }^{5)}$

범이 있음, R 병기는 재발잔류성 병변의 4단계로 구성되어 있다(Table 1, Fig. 2). 고실 전방 부위와 고실 후방 부위에 병 변이 걸쳐져 있는 경우는 P 병기로 분류하였으며, 상고실(attic portion)을 침범한 경우는 $\mathrm{M}$ 병기로 분류하였다. $\mathrm{R}$ 병기 는 진주종을 근절하기 위한 일 차적 수술 후에 다시 자라나 는 형태로 발생한 recidivistic 진주종으로 잔류 진주종과 재 발성 진주종 두 가지 부류가 있으나, 실제로 임상에서 이를 쉽게 구별하기는 힘들므로 R 병기에는 이 두 가지를 모두 포 함하였다.

\section{연구 방법}

모든 대상 환자에서 Potsic 등 ${ }^{10}$ 의 병기를 사용하였을 경 우와 $\mathrm{Kim}^{5}$ 의 병기를 사용하였을 경우의 병기별 재발률을 각각 분석하였으며 진주종의 재발은 술 후 1 년 이상 추적한 고막 소견 및 $\mathrm{TBCT}$ 소견상 진주종이 확인되지 않는 경우는 성공으로, 진주종에 합당한 소견이 확인되었을 때는 재발이
라고 판정하여 재발률을 계산하였다. 병기에 따른 재발률 비 교와 함께 $\mathrm{Kim}^{5}$ 의 병기를 사용하였을 때 각 병기별로 시행 된 수술 방법에 대해 비교하였으며, 이를 바탕으로 병기에 따 른 유양동절제술과 이소골성형술 시행 여부에 유의한 차이 가 있는지 분석하였다.

본 연구에서는 다군 간 비교를 위해 일원분산분석(IBM SPSS 23, IBM Corp., Armonk, NY, USA)을 이용하여 통계 학적 분석을 시행하였고, 두 군 간의 비교를 위해 카이제곱 검정을 사용하였고, 본 기관의 임상연구심의위원회(IRB)의 연구승인(승인번호: 2018-10-005-001)을 받은 후에 진행하 였다.

\section{수술 방법}

$\mathrm{Kim}^{5}$ 의 병기상 $\mathrm{A}$ 에 해당하거나, $\mathrm{P}$ 에 해당하지만 이소골 침범이 없는 경우엔 실험적 고실개방술을 우선적으로 시도 하였고, 부족한 수술 시야 등의 문제가 있을 경우 유양동절 제술이 추가되었다. 병기상 $\mathrm{P}$ 이지만 이소골 침범이 있거나 $\mathrm{M}$ 병기에 해당하는 환자들에겐 유양동절제술을 우선적으로 고려하였다. R 병기는 일 차 수술과 동일한 방법을 우선적으 로 고려하였다. 실험적 고실개방술은 후이도경유(transmeatal)법 또는 내이절개(endaural)법으로 접근하여, 고막 외이 도피판(tympanomeatal flap)을 들어 올린 후, 병변을 완전 히 제거하는 방식으로 진행하였으며, 이관 침범이 있거나 추 가적인 시야 확보 등이 필요한 경우 상고실벽을 제거하는 술 식(atticotomy)을 추가하였다. 질병이나 수술로 인한 이소골 의 손상이 없다면 고실성형술 0형 혹은 1형만으로 수술을 마 무리하였고, 이소골의 손상이 있는 경우 이소골성형술을 시 행하였는데, 이소골 상태에 따라 stapes head 위에 interpo$\operatorname{sition}(\mathrm{Si})$ 또는 columella $(\mathrm{Sc})$ 를 시행하거나, stapes footplate 위에 interposition $(\mathrm{Fi})$ 또는 columella $(\mathrm{Fc})$ 를 시행하였다. 이 
소골성형술에는 자가 침골 혹은 합성 이소골(partial ossicular replacement prostehsis 혹은 total ossicular replacement prosthesis)을 사용하였다. 유양동절제술은 대부분 외 이도보존술식(canal wall up)으로 진행하였고, 외이도 후벽 손상이 심하거나, 반규관 누공 등의 경우에선 외이도파괴술 식(canal wall down)을 택하였다. 유양동절제술을 시행하는 경우에도 이소골 손상에 따라 $\mathrm{Si}, \mathrm{Sc}, \mathrm{Fi}, \mathrm{Fc}$ 등의 이소골성형 술을 함께 시행하였으며, 이소골성형술이 필요하지 않은 경우 엔 고실성형술 0형 혹은 1형만을 시행하였다.

\section{결 과}

\section{병기 및 재발률}

Potsic 등 ${ }^{10}$ 의 병기 및 $\mathrm{Kim}^{5)}$ 의 병기에 따른 대상 환자의 분 류와 각각의 재발률은 Table 2, Fig. 3과 같다. 첫 수술군 112 예를 대상으로 Potsic 등ㅁㅇㅢ 읭기를 사용하였을 때 I기, II기, III기 및 IV기는 각각 35예, 19예, 36예 및 22예로 III기가 가 장 많았고, 병기별로 치료 성공군과 재발군을 나누어 재발률 을 분석한 결과 I기, II기, III기 및 IV기의 재발률은 각각 $0 \%, 21 \%, 17 \%$ 및 $23 \%$ 의 결과를 보여 I기가 II기보다 재발률

Table 2. Recurrence rates according to the stage using Potsic classification and Kim classification

\begin{tabular}{ccccc}
\hline Author & Stage & Cured cases (\%) & Recurred cases (\%) & Total \\
\hline Potsic & I & $35(100)$ & $0(0)$ & 35 \\
et al. $^{10)}$ & II & $15(79)$ & $4(21)$ & 19 \\
& III & $30(83)$ & $6(17)$ & 36 \\
& IV & $17(77)$ & $5(23)$ & 22 \\
\hline & Total & $97(87)$ & $15(13)$ & 112 \\
\hline Kim $^{5)}$ & A & $42(91)$ & $4(9)$ & 46 \\
& P & $37(86)$ & $6(14)$ & 43 \\
& M & $18(78)$ & $5(22)$ & 23 \\
& R & $17(68)$ & $8(32)$ & 25 \\
\hline & Total & $114(83)$ & $23(17)+5^{*}$ & 137
\end{tabular}

* five revision cases performed at an outside hospital are marked separately due to the lack of clinical records
이 유의하게 낮았으나 $(p=0.012)$ II기, III기 및 IV기 간의 유 의한 차이는 없었으며 오히려 II기가 III기보다 높은 재발률 을 보여, 병기와 재발률 간에 일정한 연관성이 확인되지 않 았다. $\mathrm{Kim}^{5}$ 병기의 경우 재발잔류군인 R 병기가 포함되어 따 로 분류되어 있기 때문에, Potsic 드이) 병기의 분류에서 포함 한 첫 수술군 112예 이외에도 재수술 예들이 포함되었다. 재 수술군 30예 중에 타원에서 첫 번째 수술을 받아, 수술 내용 을 알 수 없는 5예는 제외하고 25예만을 포함시켰다. 병기별 분포는 A 병기, P 병기, M 병기 및 R 병기는 각각 46예(34\%), 43예(31\%), 23예(17\%) 및 25예(18\%)였으며, 가장 낮은 병기인 $\mathrm{A}$ 에 해당하는 예가 가장 많았다. 병기별 재발률을 분석한 결과 A 병기, P 병기, M 병기 및 R 병기의 재발률은 각각 $9 \%$, $14 \%, 22 \%$ 및 $32 \%$ 로 측정되어 Potsic 등 ${ }^{10}$ 의 병기와 달리 병 기가 높아짐에 따라 재발률이 높은 경향을 보였다. 인접한 병 기인 A 병기와 P 병기, P 병기와 M 병기, M 병기와 R 병기를 직접 비교할 경우에는 유의한 차이는 없었으나, 재수술군이 자 가장 높은 병기에 해당하는 $\mathrm{R}$ 병기를 따로 분류하여 첫 수술군에 해당하는 $\mathrm{A}$ 병기와 $\mathrm{P}$ 병기와 $\mathrm{M}$ 병기를 합한 군과 비교하면 $\mathrm{R}$ 병기에서 유의하게 높은 재발률을 보였다 $(p<$ 0.037).

\section{수술 방법}

$\mathrm{Kim}^{5)}$ 의 병기에 따라 $\mathrm{A}$ 병기, $\mathrm{P}$ 병기, $\mathrm{M}$ 병기 및 $\mathrm{R}$ 병기로 나누었을 때 각 병기별로 유양돌기절제술 및 이소골성형술 이 시행된 비율은 Table 3, Fig. 4와 같다. A 병기에서는 46예 중 36예(78\%)에서 실험적 고실개방술만 시행하였고(78\%), 유 양동절제술을 필요로 했던 환자는 46명 중 10예(22\%)였다. 유양동절제술을 시행한 경우는 모두 폐쇄형 유양동절제술이 었으며, 개방형 유양동절제술은 없었다. P 병기와 M 병기에 서는 유양동절제술을 시행한 환자군이 각각 $67 \%, 100 \%$ 로 관찰되어 $\mathrm{A}$ 병기보다 $\mathrm{P}$ 병기에서, $\mathrm{P}$ 병기보다 $\mathrm{M}$ 병기에서 유 양동절제술을 시행한 경우가 유의하게 많았다 $(p<0.05)$. 첫 수술군인 A 병기와 P 병기와 $\mathrm{M}$ 병기를 합한 군과 재수술군
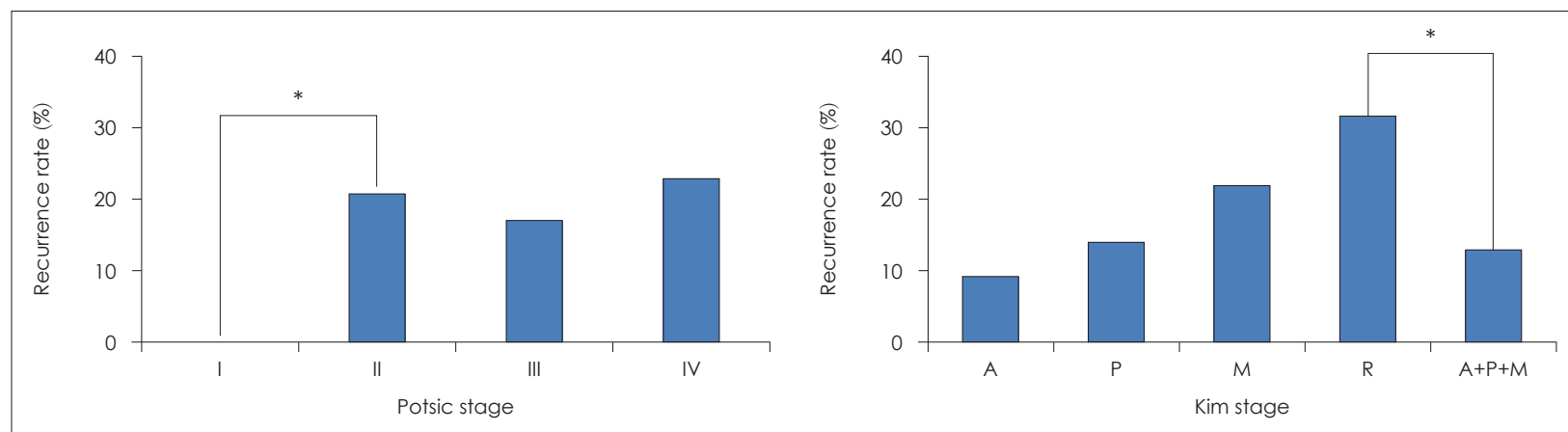

Fig. 3. Recurrence rate according to Potsic or Kim staging system. ${ }^{*} p<0.05$. 
인 R 병기를 비교할 경우, 유양동절제술 시행 유무에 유의한 차이는 없었다 $(p=0.684)$. 이소골성형술 여부에 따라 분석하 였을 때 병기 $\mathrm{A}$ 에서는 대부분 이소골성형술 없이 고실성형 술 0형 혹은 고실성형술 1형만 시행하였고, 이소골성형술을 시행한 환자는 46명 중 2명(4\%)으로 낮았다. P 병기, M 병기 및 R 병기에서는 이소골성형술을 시행한 환자군이 각각 $67 \%$, $83 \%$ 및 $43 \%$ 로 확인되어 A 병기에 비해 $\mathrm{P}$ 병기에서 이소골성 형술이 필요한 경우가 유의하게 많았으나 $(p<0.05) \mathrm{P}$ 병기와 $\mathrm{M}$ 병기 사이에는 유의한 차이가 없었고, 첫 수술군과 재수 술군인 R 병기를 비교할 경우에도 이소골성형술 시행 유무 에는 유의한 차이가 없는 것으로 나타났다 $(p=0.684)$.

\section{고 찰}

선천성 중이진주종은 소아에서 주로 호발하며, 성인에서 발생하는 후천성 진주종과는 다소 다른 임상 소견을 보여 이 에 맞는 적절한 진단 및 조치가 필요하다. 선천성 진주종의 경우, 후천성 진주종과는 다르게 이관 기능이 정상이고 대부 분 진주종 주위 염증이 동반되지 않으면서 측두골의 함기화 가 잘 되어 있는 경우가 많기 때문에 광범위한 유양동절제술 없이 진주종의 제거만으로 치료가 가능한 경우가 드물지 않 다. 그러나 가끔 진주종 병변의 광범위한 침습이 일어날 수

Table 3. Comparison of mastoidectomy and/or ossiculoplasty performed according to the group of Kim staging system

\begin{tabular}{cccccccc}
\hline \multirow{2}{*}{ Stage } & \multicolumn{3}{c}{ Mastoidectomy } & & \multicolumn{3}{c}{ Ossiculoplasty } \\
\cline { 2 - 3 } \cline { 7 - 8 } \cline { 7 - 8 } & No (\%) & Yes (\%) & Total & & No (\%) & Yes (\%) & Total \\
\hline A & $36(78)$ & $10(22)$ & 46 & & $44(96)$ & $2(4)$ & 46 \\
$P$ & $14(33)$ & $29(67)$ & 43 & & $14(33)$ & $29(67)$ & 43 \\
$M$ & $0(0)$ & $23(100)$ & 23 & & $4(17)$ & $19(83)$ & 23 \\
R & $10(43)$ & $13(57)$ & $23+5^{*}$ & & $10(43)$ & $13(57)$ & $23+5^{*}$ \\
\hline Total & $60(44)$ & $75(56)$ & 135 & & $72(53)$ & $63(47)$ & 135 \\
\hline
\end{tabular}

* five revision cases performed at an outside hospital are marked separately due to the lack of clinical records
있고, 수술 후 재발하는 경우가 드물지 않기 때문에 수술계 획을 세울 때 진주종의 위치, 범위와 심한 정도를 정확하게 파악하는 것이 필수적이다.,15)

이전 연구에서는 $6,8-10)$ 선천성 중이진주종의 첫 번째 수술적 제거 후 재발률은 29.5 52\%로 매우 높게 보고하였으나 최근 연구에서의 ${ }^{16,17)}$ 재발률은 9.9 18.9\%로 이전보다 낮게 보고되 고 있다. 본 연구에서는 첫 수술로서 시행받은 112예의 환자 중에서 재발한 환자는 15 예로 $13 \%$ 의 재발률을 보였고, 재수 술을 시행받은 30예의 환자 중에서 다시 재발한 경우는 8예 로 $27 \%$ 의 재발률을 보여 최근 연구 보고의 결과들과 비슷한 것으로 나타났다. 이것은 고해상 $\mathrm{TBCT}$ 와 내시경 진단의 발 달에 힘입어 점점 빨라지는 조기 진단으로 인해 많이 진행되 지 않은 초기병변에서 진단되고, 이에 따라 술 후 재발률이 낮아진 것으로 생각된다.

선행 연구들에 따르면 선천성 중이진주종의 술 후 재발에 관여하는 인자로, 진주종의 유형, 이소골의 손상 여부, 성별 및 연령, 증상 지속기간, 진주종의 크기 및 위치, 측두골 함기 화 등 여러 인자들이 언급되고 있으나, ${ }^{711-13)}$ 진주종의 병기에 따른 예후의 차이에 대해선, 그 연구가 충분치 않은 상태다.

선천성 중이진주종의 병기체계로는 Potsic 등ㅁㅇㅢ 븨눈류가 널리 알려져 있는데, 임상적으로 유용한 병기체계란 각 병기 의 구분이 명확해야 하고, 병기에 따른 치료 방침을 정할 수 있으며, 치료 후 예후를 예측할 수 있어야 한다는 점을 고려 할 때, Potsic 등 ${ }^{10)}$ 의 병기체계는 몇 가지 보완되어야 할 필요 가 있었다. 첫째는 후고실의 병변을 이소골의 침범 여부로 II 기와 III기로 구분하고 있으나 실제 임상적으로는 이소골 손 상을 정량적 분석이 아닌 이소골 침범 유무만으로 이분법적 으로 분류할 경우, 이소골 침범 유무와 술 후 예후와의 상관 성이 크지 않다는 점이며, 둘째는 병기에 따른 예후 또는 재 발률과 병기에 따른 수술법을 명확히 제시하고 있지 않다는 점이다. 이를 보완하여 최근에 $\mathrm{Kim}^{5)}$ 의 병기체계가 새로 제 안되었는데 이 체계의 한 가지 특징은 재수술군을 하나의 병

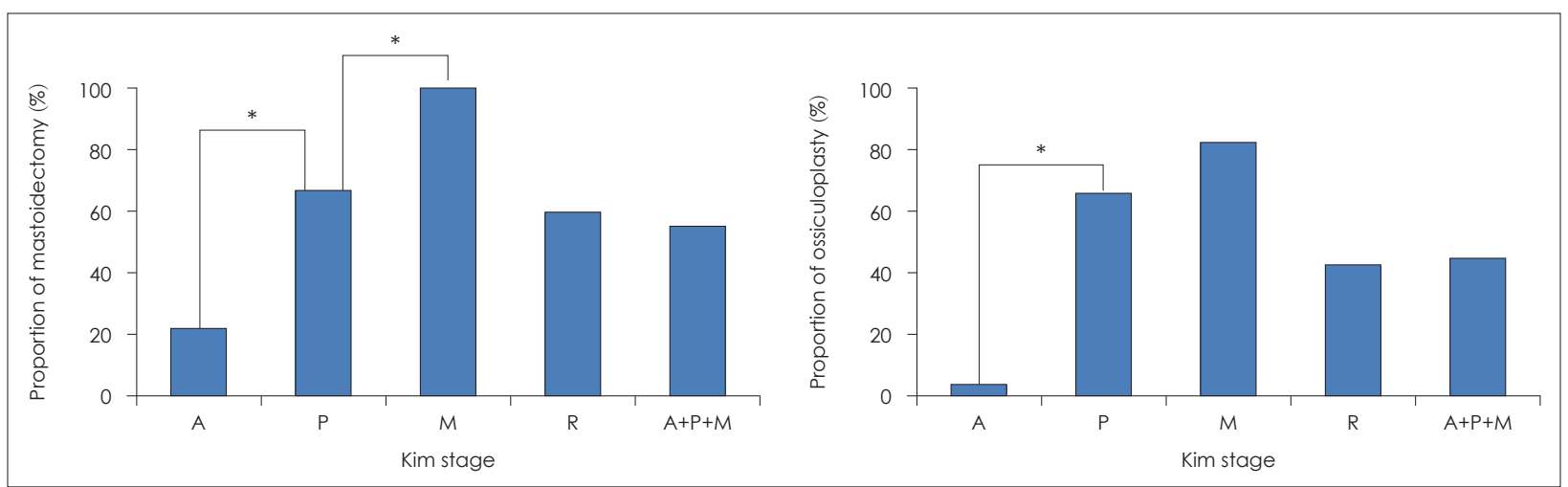

Fig. 4. Comparison of mastoidectomy or ossiculoplasty according to Kim staging system. ${ }^{*} p<0.05$. 
기로 따로 설정하고 있다는 것이다. 선천성 진주종 수술 후에 재발된 진주종은 정의상으로는 선천성 중이진주종에 포함되 지 않지만 재발된 진주종도 원발성 진주종과 매우 유사한 술 전 임상상을 보이고, 수술 방법도 비슷한 술기를 선택하는 경 우가 많으며 특히, 술 후 재발률은 상대적으로 높지만 그 양 상은 비슷하다는 점에서 이를 병변의 한 단계로서 따로 분류 하는 것이 유용하다고 판단하였기 때문이다.

본 연구에서는 기존의 병기체계인 Potsic 등 ${ }^{10}$ 의 병기와 새 로운 $\mathrm{Kim}^{5)}$ 의 병기에 따른 치료결과를 분석하여 비교해 보 았으며, $\mathrm{Kim}^{5}$ 의 병기를 사용할 경우 각 병기에 따른 수술 방 법의 차이가 있는지 함께 분석하였다. 기존의 Potsic 등이 의 병기를 사용하였을 때 I기에서 $0 \%$ 의 재발률로 다른 병기에 비해 유의하게 재발률이 낮은 것으로 나타나서 술 후 예후인 자를 판단하는 데 있어 유용한 도구임을 확인할 수 있었지만 II기, III기 및 IV기 사이에는 재발률에 유의한 차이가 없었 으며 병기 증가에 따른 재발률의 변화에 연관성이 확인되지 않았다. 하나의 quadrant에만 국한된 1기에 해당하는 경우 가 아니라면, 예후를 예측하기에는 한계가 있을 것으로 사료 되었다. $\mathrm{Kim}^{5}$ 의 병기체계를 사용하였을 때 첫 수술군인 $\mathrm{A}$ 병기, P 병기와 M 병기를 함께 포함한 예에 비해, 재수술군 인 R 병기에서 재발률이 유의하게 높은 것으로 확인되어, 재 발된 진주종을 하나의 독립된 병기로 분류하는 것이 치료 후 예후인자를 예측하는 데 있어 유용할 수 있음을 확인할 수 있었다. 인접한 병기인 A 병기와 P 병기, P 병기와 M 병기, $\mathrm{M}$ 병기와 R 병기 사이의 재발률을 분석하였을 때, 통계적으 로 유의한 차이는 아니었지만 전반적으로 APMR 병기가 높 아질수록 재발률이 높아지는 경향은 확인되었다. 진주종의 위치가 전방보다 후방, 특히 후상방에 위치한 경우 재발이 높은 이유에 대해 Iino 등 ${ }^{13)}$ 은 진주종이 후상방에 위치한 경 우 침골의 장각 및 등골의 상완각 손상, 그리고 진주종의 고
실동 침범이 흔하게 나타나기 때문이라고 설명한 바 있다.

$\mathrm{Kim}^{5}$ 의 병기에 따른 수술 방법을 분석하였을 때, A 병기 보다 P 병기에서 유양동절제술 및 이소골성형술이 필요한 경우가 유의하게 많았다. 이는 고실 전방부 국한 병변에서는 실험적 고실개방술만으로 병변의 전적출이 가능할 때가 많 지만 고실 후방부 병변의 경우 이소골 침범이 있는 경우가 많 으므로 이소골성형술을 필요로 하거나 시야 확보를 위해서 유양동절제술 및 후고실접근법(posterior tympanotomy)을 선택해야 하는 경우가 많기 때문으로 해석된다. ${ }^{5} \mathrm{P}$ 병기와 $\mathrm{M}$ 병기를 비교할 때에는, $\mathrm{M}$ 병기의 경우 모든 증례에서 유양동 침범이 있으므로 $\mathrm{P}$ 병기에서보다 유양동절제술을 필요로 하 는 경우가 유의하게 많은 것으로 나타났다. 하지만 유양동절 제술과는 달리 이소골성형술 시행 여부에는 유의한 차이가 없었기 때문에, 진주종의 유양동 침범이 반드시 이소골성형 술의 필요성을 높이지는 않는 것으로 해석되었다. 한편 잔존 성 진주종이 재발하였을 때 임상적 측면에서 원발성 진주종 과 유사한 양상을 보이기 때문에 수술적 접근법도 비슷한 술 기를 선택하는 경우가 대부분인데 ${ }^{5}$ 이번 연구에서도 역시 일 차 수술인 A 병기+P 병기+M 병기군과 재수술인 R 병기 사 이에 유양동절제술 및 이소골성형술 시행 여부에는 유의한 차이가 없는 것으로 확인되었다.

저자들은 약 29년간 142 예의 선천성 중이진주종 수술경험 을 바탕으로 한 본 연구의 결과를 통해 진주종 병기에 따른 치료계획으로 다음과 같은 치료계획 알고리즘을 제시하고자 한다. A 병기에서는 실험적 고실개방술을 선택하되 이관입 구 침범 정도에 따라 전상부 고실 측벽 골부를 제거하는 술 식을 추가할 수 있고, P 병기에서는 이소골 파괴 여부에 따라 실험적 고실개방술 혹은 폐쇄형 유양동절제술을 추가할 수 있으며, M 병기에서는 이소골이 정상인 경우는 유양동절제 술과 고실개방술을 함께 하고, 이소골이 파괴된 경우에 이소

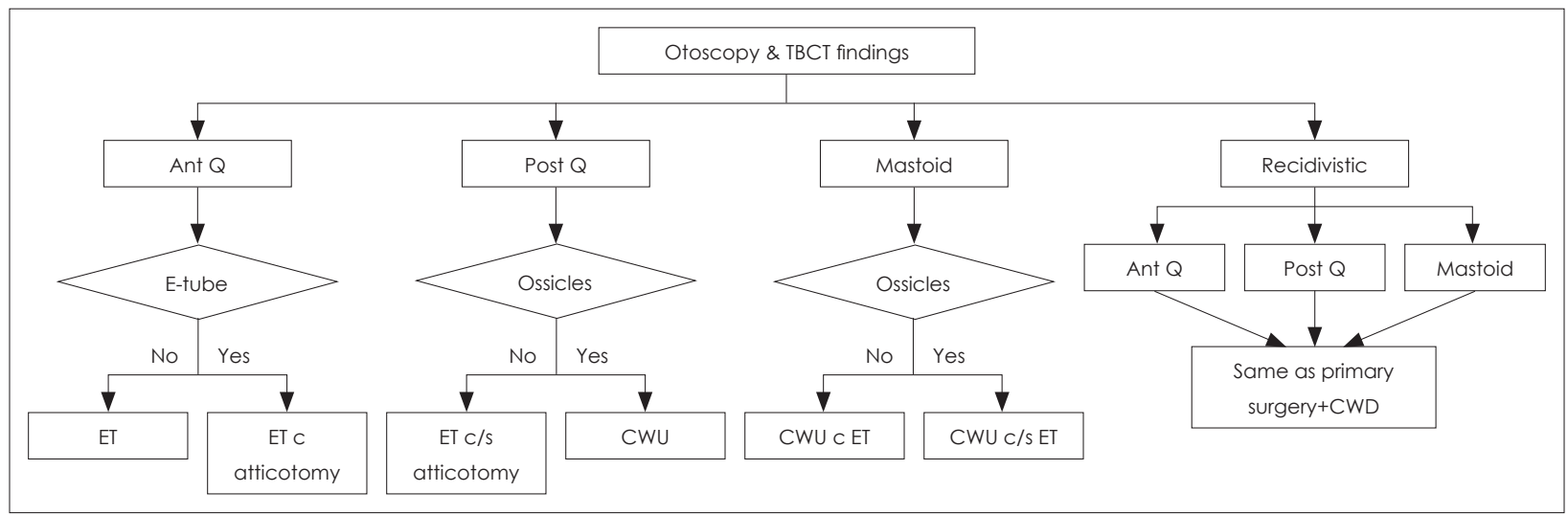

Fig. 5. Surgical approach algorithm for congenital cholesteatoma. TBCT: temporal bone computerized tomography, E: eustachian, Q: quadrant, ET: exploratory tympanotomy, CWU: canal wall up mastoidectomy, CWD: canal wall down mastoidectomy. 
골성형술을 추가할 수 있는데, 이때 후상방에 국한된 진주종 이라면 침골의 제거와 광범위 후고실접근법(wide posterior tympanotomy)을 통해 충분한 수술 시야를 확보할 수 있어 진주종의 완전제거가 가능해지므로 고막 외이도피판을 들어 올리지 않아도 되어, 보다 안정된 이소골성형술을 시행할 수 있게 된다. $\mathrm{R}$ 병기에서는 $\mathrm{A}$ 병기 $+\mathrm{P}$ 병기 $+\mathrm{M}$ 병기군의 일차 수술과 동일한 알고리즘을 따르되 외이도 후벽 손상이 심한 경우, 반규관 누공, 협소한 경화성 유양 돌기, 또는 유일청 귀 등에서는 개방형 유양동절제술 접근법이 필요하다(Fig. 5).

본 연구의 제한점으로는 첫째, 후향적 연구로 진행이 되었 다는 점이며 둘째, 병기에 따른 진주종의 재발률만을 관찰 하였을 뿐, 진주종의 유형, 이소골의 손상 여부, 수술 방법 등, 진주종의 재발에 영향을 줄 수 있는 다른 예후인자를 반영 하지 않았다는 점을 들 수 있다. 그러므로 병기와 재발률과 의 관계를 명확히 하기 위해 타 기관 공동연구와 같은 방법 을 통해 다른 예후인자들을 보정할 필요가 있고, 전향적 연 구를 통해 보완된 후속 연구가 필요할 것으로 생각된다.

결론적으로, 선천성 중이진주종의 예후 예측이라는 측면 에서, 기존의 Potsic 등미의 병기체계와 새롭게 제안된 $\mathrm{Kim}^{5}$ 의 병기체계 두 가지 모두 유용한 정보를 제공할 수 있으며 $\mathrm{Kim}^{5)}$ 의 병기체계는 Potsic 등이의 병기체계와는 달리, 병기에 따른 적절한 치료방안을 제안해줄 수 있는 새로운 병기체계 로, 선천성 중이진주종 환자의 평가 및 치료에 적절한 지침이 될 수 있을 것으로 생각된다.

\section{Acknowledgments}

This study was supported by the National Research Foundation of Korea (NRF) grant funded by the Korean Government (2018R1D1A1B07045305)

\section{ORCID}

Hyung-Jong Kim https://orcid.org/0000-0001-9020-6026

\section{REFERENCES}

1) Grundfast KM, Ahuja GS, Parisier SC, Culver SM. Delayed diagnosis and fate of congenital cholesteatoma (Keratoma). Arch Otolaryngol
Head Neck Surg 1995;121(8):903-7.

2) Karmarkar S, Bhatia S, Khashaba A, Saleh E, Russo A, Sanna M. Congenital cholesteatomas of the middle ear: A different experience. Am J Otol 1996;17(2):288-92.

3) Sanna M, Zini C. "Congenital cholesteatoma" of the middle ear. A report of 11 cases. Am J Otol 1984;5(5):368-73.

4) Romanet P. Congenital cholesteatoma. Proceedings: 6th International Conference on Cholesteatoma \& Ear Surgery. Amsterdam: Kugler Publ;2001. p.315-20.

5) Kim HJ. Congenital cholesteatoma: Diagnosis and management. Korean J Otorhinolaryngol-Head Neck Surg 2013;56(8):482-9.

6) Levenson MJ, Parisier SC, Chute P, Wenig S, Juarbe C. A review of twenty congenital cholesteatomas of the middle ear in children. Otolaryngol Head Neck Surg 1986;94(5):560-7.

7) Yoo SW, Kwon SY, Kim HJ. Risk factors of post-operative recidicism in congenital cholesteatoma of the middle ear. Korean $\mathrm{J}$ Otorhinolaryngol-Head Neck Surg 2014;57(10):664-70.

8) Friedberg J. Congenital cholesteatoma. Laryngoscope 1994;104 (3 Pt 2):1-24.

9) Levenson MJ, Michaels L, Parisier SC. Congenital cholesteatomas of the middle ear in children: Origin and management. Otolaryngol Clin North Am 1989;22(5):941-54.

10) Potsic WP, Samadi DS, Marsh RR, Wetmore RF. A staging system for congenital cholesteatoma. Arch Otolaryngol Head Neck Surg 2002;128(9):1009-12.

11) Lazard DS, Roger G, Denoyelle F, Chauvin P, Garabédian EN. Congenital cholesteatoma: Risk factors for residual disease and retraction pockets--a report on 117 cases. Laryngoscope 2007;117 (4):634-7.

12) Stapleton AL, Egloff AM, Yellon RF. Congenital cholesteatoma: Predictors for residual disease and hearing outcomes. Arch Otolaryngol Head Neck Surg 2012;138(3):280-5.

13) Iino Y, Imamura Y, Kojima C, Takegoshi S, Suzuki JI. Risk factors for recurrent and residual cholesteatoma in children determined by second stage operation. Int J Pediatr Otorhinolaryngol 1998;46(12):57-65.

14) Nelson M, Roger G, Koltai PJ, Garabedian EN, Triglia JM, Roman $\mathrm{S}$, et al. Congenital cholesteatoma: Classification, management, and outcome. Arch Otolaryngol Head Neck Surg 2002;128(7):810-4.

15) Levi J, Grindle C, O'Reilly R. Pie-slice tympanoplasty for transcanal removal of small congenital cholesteatoma. Int J Pediatr Otorhinolaryngol 2012;76(11):1583-7.

16) Choi HG, Park KH, Park SN, Jun BC, Lee DH, Park YS, et al. Clinical experience of 71 cases of congenital middle ear cholesteatoma. Acta Otolaryngol 2010;130(1):62-7.

17) Kim DK, Kim HM, Suh MW, Lee JH, Oh SH, Kim CS, et al. Analysis of risk factors for the occurrence of residual cholesteatoma after congenital cholesteatoma surgery. Korean J OtorhinolaryngolHead Neck Surg 2008;51(2):120-4. 